\title{
Methods to Study Metastasis in Genetically Modified Mice
}

\author{
Farhia Kabeer, ${ }^{1,3}$ Levi J. Beverly, ${ }^{4,5}$ Guillaume Darrasse-Jèze, ${ }^{6,7,8}$ and Katrina Podsypanina1,2,3,9 \\ ${ }^{1}$ Institut de Recherches Cliniques de Montréal, Montréal, Quebec H2W 1R7, Canada; ${ }^{2}$ Pathologie et Biologie \\ Cellulaire, Université de Montréal, Montréal, Quebec H3T 1J4, Canada; ${ }^{3}$ Department of Medicine, Experimental \\ Medicine Division, McGill University, Montréal, Quebec H3A 1A3, Canada; ${ }^{4}$ Department of Medicine, University \\ of Louisville, Louisville, Kentucky 40202; ${ }^{5}$ Department of Pharmacology and Toxicology, University of Louisville, \\ Louisville, Kentucky 40202; ${ }^{6}$ Université Pierre et Marie Curie, Université Paris 06, Unité Mixte de Recherche \\ 7211; INSERM, Unité Mixte de Researche S959, R3, F-75013 Paris, France; ${ }^{7}$ Université Paris Descartes, \\ Sorbonne Paris Cité, Hôpital Necker-Enfants Malades, Faculté de Médecine Paris Desecartes; INSERM, Unité \\ 1013, F-75015 Paris, France; ${ }^{8}$ Laboratory of Molecular Immunology, The Rockefeller University, New York, \\ New York 10065
}

\begin{abstract}
Metastasis is often modeled by xenotransplantation of cell lines in immunodeficient mice. A wealth of information about tumor cell behavior in the new environment is obtained from these efforts. Yet by design, this approach is "tumor-centric," as it focuses on cell-autonomous determinants of human tumor dissemination in mouse tissues, in effect using the animal body as a sophisticated "Petri dish" providing nutrients and support for tumor growth. Transgenic or gene knockout mouse models of cancer allow the study of tumor spread as a systemic disease and offer a complimentary approach for studying the natural history of cancer. This introduction is aimed at describing the overall methodological approach to studying metastasis in genetically modified mice, with a particular focus on using animals with regulated expression of potent human oncogenes in the breast.
\end{abstract}

\section{METASTASIS THEORIES}

A classical theory generated in the 1970s predicts that metastases arise from genetically determined subpopulations in primary tumors (Fidler 1973). Indeed, the ability of gene-expression profiles of human primary carcinomas to predict metastasis risk (van 't Veer et al. 2002; Ramaswamy et al. 2003; Wang et al. 2005) suggests that the metastatic ability of tumors is acquired by a linear progression to a distinct genetic program in cells of the primary tumor (Kang et al. 2003; Minn et al. 2005). On the other hand, analysis of single disseminated cancer cells led to a hypothesis that metastatic disease evolves independently from the primary tumor (Klein 2009; Stoecklein and Klein 2010). The parallel theory of metastasis is based on observations that the genomic alterations of disseminated tumor cells in patients often do not resemble those of the primary tumors (Schmidt-Kittler et al. 2003). In short, some cancers appear to evolve at the primary site and metastatic variants are then selected at the periphery, and others appear to disseminate early, so that metastatic evolution proceeds at the ectopic site. Genetically engineered mouse models of cancer serve as an important tool in the search for a unifying theory of metastasis, and provide experimental ways to take into account both of these theories (Husemann and Klein 2009).

\footnotetext{
${ }^{9}$ Correspondence: podsypak@gmail.com

(c) 2016 Cold Spring Harbor Laboratory Press

Cite this introduction as Cold Spring Harb Protoc; doi:10.1101/pdb.top069948
} 
F. Kabeer et al.

\section{GENETICALLY MODIFIED MOUSE MODELS OF METASTATIC DISEASE}

Despite significant advances in our understanding of cancer, metastasis remains the main cause of cancer-related mortality. Once established, metastatic disease is difficult to eliminate, as it often becomes inaccessible to surgical treatment and insensitive to chemotherapy. Different metastatic cancers can have vastly different natural histories that likely represent pathogenetically unrelated diseases. Mouse models of metastatic cancer are only beginning to capture this diversity, and new and improved models to study metastasis would greatly benefit the metastasis research field. Tissuespecific oncogene expression (and/or tumor-suppressor loss) has been used to induce metastatic cancer in many tissues, including liver (Shachaf et al. 2004; Lewis et al. 2005), breast (reviewed in Fantozzi and Christofori 2006; Vernon et al. 2007; Bos et al. 2010), colon (reviewed in Heijstek et al. 2005), lung (Meuwissen et al. 2003; Rapp et al. 2009; Winslow et al. 2011), skin (Landsberg et al. 2010; Damsky et al. 2011; Schiffner et al. 2012), pancreas (Tevethia et al. 1997; Hingorani et al. 2005; Bardeesy et al. 2006; Rhim et al. 2012), ovary (reviewed in Sale and Orsulic 2006), and prostate (Gingrich et al. 1996; Han et al. 2005; Moore et al. 2008). In transgenic cancers, metastatic sites are often identical in different models, perhaps reflecting tropism in the tissue of origin of the primary tumor. For example, mammary tumors produce metastatic colonies almost exclusively in the lung (reviewed in Vernon et al. 2007), and pancreas and colon tumors metastasize to the liver (Qian et al. 2001; Shachaf et al. 2004; Heijstek et al. 2005; Morton et al. 2008). Other tumors, such as lung or prostate, have a less predictable pattern of dissemination. Some cancers in humans also display a recurrent order of the systemic spread, but advanced metastatic disease in humans rarely affects only a single organ.

Historically, metastatic disease in a new cancer model has been detected by conventional gross and microscopic histopathological inspection at the time of tumor harvest. In the absence of clear "clinical" symptoms (usually signs of organ failure), the lung, liver, spleen, and kidneys of the tumorbearing mice are commonly evaluated for evidence of visceral metastases, followed by the search for brain metastases and skeletal metastases in major bones. The more recent whole-body imaging methods such as magnetic resonance imaging (MRI), micro-computed tomography (micro-CT), positron emission tomography (PET), and bioluminescence imaging (Acuff et al. 2006; Deroose et al. 2007; Fushiki et al. 2009; Kirsch et al. 2010; Krupnick et al. 2012) permit a "live" metastasis scan of an entire body of a mouse with cancer; see Introduction: Noninvasive Imaging of Tumor Burden and Molecular Pathways in Mouse Models of Cancer (Wang et al. 2014).

In genetically modified mouse models, the metastatic phenotype is often linked to the genotype of the primary tumor. Loss of the tumor-suppressor genes Trp53, Pten, or $R b$ have all repeatedly been shown to promote neoplastic disease to the systemic stage, regardless of the tumor type studied (Maroulakou et al. 1997; Fedorov et al. 2003; Lin et al. 2004; Calbo et al. 2005; Lewis et al. 2005; Ridgeway et al. 2006; Chen et al. 2007; Berman et al. 2008; Morton et al. 2008; Dankort et al. 2009; Guigon et al. 2009; Puzio-Kuter et al. 2009; Schade et al. 2009; Antico Arciuch et al. 2011). Although the pleiotropic effects of inactivation of these genes, which include the induction of genomic instability (Yin et al. 1992; Fukasawa et al. 1996; Puc et al. 2005; Coschi et al. 2010; Manning et al. 2010; van Harn et al. 2010), altered cell-cycle progression, and the reprogramming of chromatin (for review, see Beckerman and Prives 2010; Fiorentino et al. 2013), make it challenging to link a specific effect of tumor-suppressor deficiency to a given step in a metastatic cascade, this does not diminish the value of tumor-suppressor-deficient backgrounds as a reliable way to reveal metastatic abilities in models that are not metastatic. It is particularly relevant in light of frequent tumor-suppressor loss in human cancers.

\section{USING GENETICALLY MODIFIED MICE TO STUDY METASTASIS}

\section{Identification of Genes that Regulate Metastasis}

Genetically modified mice have been long used to identify or validate specific factors that regulate metastasis. One of the most widely studied models of metastatic progression is an insulinoma model 
(Hanahan 1985). Expression of the SV40 viral oncogene under the control of the rat insulin promoter leads to gradual transformation and tumorigenesis in the pancreatic islets. Recurrent changes associated with the advanced disease in this model (e.g., up-regulation of the insulin-like growth factor receptor, IGF-1R) have been found to be important for metastasis (Lopez and Hanahan 2002). Somatic delivery of candidate progression genes in this model has led to identification of metastasis-inducing properties of the antiapoptotic molecule BclX-L (Du et al. 2007) and of the receptor for hyaluronan-mediated motility isoform B (Du et al. 2011). Additionally, many metastatic factors have been validated using Rip-TAg mice, including neural cell adhesion molecule (Perl et al. 1999; Crnic et al. 2004), E-cadherin (Perl et al. 1998; Du et al. 2007), and vascular endothelial growth factor-C (Mandriota et al. 2001). One of these factors, $\beta 1$-integrin (Kren et al. 2007), regulates metastatic progression in other cancer models-for example, in the MMTV-PyMT (Guy et al. 1992) and in the MMTV-Neu (Muller et al. 1988) models of metastatic breast cancer (reviewed in Lahlou and Muller 2011).

A gene that consistently regulates metastatic behavior of cancer cells across a variety of transgenic cancer models is TGF- $\beta 1$ (Yang et al. 2002, 2008; Siegel et al. 2003; Tu et al. 2003; Muraoka-Cook et al. 2004; Borczuk et al. 2011). TGF- $\beta 1$ enhances the proliferation of cells of mesenchymal origin and inhibits the proliferation of many types of epithelial cells. TGF- $\beta 1$ acts by binding to the type II TGF- $\beta$ receptor (TRRII), which is constitutively active as a serine/threonine kinase (Heldin et al. 1997; Massague and Chen 2000). TGF- $\beta$ signaling appears to play a role in the development of disseminated disease by acting both cell autonomously and as a systemic factor (Forrester et al. 2005; Fang et al. 2011). In this regard, either gain or loss of TGF- $\beta$ signaling may promote metastasis, depending on the cell type or cellular context (reviewed in Bierie and Moses 2009). It is speculated that the metastasis-related effects of TGF- $\beta 1$ are mediated by the tumor microenvironment, such as endothelial cells, immune cells, and fibroblasts. For example, acute repression of TGF- $\beta$ signaling in Kras-induced lung tumors promotes lymph node metastasis associated with an immunosuppressed tumor microenvironment (Borczuk et al. 2011). Similarly, acute ablation of TGF- $\beta$ signaling in MMTV-PyMT mammary tumor cells leads to a fivefold increase in lung metastasis (Bierie et al. 2008), possibly via increase in the number of infiltrating Th17 (Novitskiy et al. 2011) and/or Gr-1+CD11b+ myeloid cells (Yang et al. 2008). However, transgenic mice expressing a soluble TGF- $\beta$ antagonist (T $\beta R I I: F c$ fusion protein) are resistant to the development of metastases at multiple organ sites in an MMTV-Neu breast cancer model (Yang et al. 2002). Cross-validation of a metastasis factor in cancers induced in different genetic contexts or in distinct tissues is an excellent strategy to broaden the relevance of a metastasis study.

The metastatic process consists of a number of steps: local invasion and intravasation, transport through the circulation, extravasation, formation of a micrometastasis, and, finally, development of overt metastatic tumors (Faltas 2012). Some of these steps, especially at the beginning and at the end of the cascade, appear to be more challenging for tumor cells to accomplish (Chambers et al. 2000). Intuitively, a number of distinct changes must occur within tumor cells to enable them to complete the metastatic process. In support of this view, a number of genes have been shown to modify the metastatic behavior of primary cancers. Many of these genes have been validated in vivo by demonstrating that in complex genetically altered mice known to develop metastatic cancer, the loss of expression of a metastatic modifier decreases penetrance of a metastatic phenotype (recent examples include urokinase [Almholt et al. 2005], caveolin 1 [Williams et al. 2004, 2005], flotillin-2 [Berger et al. 2012], tetraspanin CD151 [Copeland et al. 2012], Elf5 [Chakrabarti et al. 2012], macrophage inhibitory cytokine-1 [Husaini et al. 2012], breast cancer metastasis suppressor 1 [Cook et al. 2012], KiSS1 [Cho et al. 2012], and Nm22 [Marino et al. 2012]). On the other hand, there is evidence suggesting that both dissemination and colonization at the ectopic site can be determined by the same genes that drive growth of the primary tumor (Husemann et al. 2008; Podsypanina et al. 2008a; Rhim et al. 2012).

\section{Determination of the Therapeutic Value of Metastasis-Related Genes Discovered} in Mouse Models

One possible prediction from the multistep model for the establishment of metastatic disease is that the additional mutations acquired during the metastatic process would supercede the cells' continued 
F. Kabeer et al.

requirement for the initial oncogenic driver mutation that was necessary at the primary site of disease. However, this appears to not be the case, as several examples show an exquisite sensitivity in both the primary lesion and distant metastatic lesions to the continued activity of the initiating oncogenic mutation. Although the published record of this dependency in experimental models is still short (Moody et al. 2002; Gunther et al. 2003; Shachaf et al. 2004; Dankort et al. 2009), it faithfully recapitulates clinical situations where effective targeted therapies are used to treat patients with metastatic cancer (Stahel et al. 2003; Hotta et al. 2004; Schneeweiss et al. 2004; Flaherty et al. 2010). These observations argue that metastasis-promoting mutations are not, in many instances, capable of protecting the metastatic lesions from therapeutics that inhibit the primary oncogenic driver. However, this observation does not exclude the importance of testing whether inhibition of metastatic modifier genes might effectively block tumor relapse at metastatic sites and could therefore represent potential therapeutic targets against advanced cancers.

\section{Lineage Tracing in Metastatic Models}

The inefficiency of the metastatic process and lack of putative metastasis-specific markers make it challenging to trace the origin of metastatic cells. No clonal lineage-tracing experiments have been performed to date to trace the fate of individual metastasis-initiating cells in transgenic mice, although many studies have investigated the tumor-initiating potential of the specific cell subsets from transplantable tumors (for reviews, see Charafe-Jauffret et al. 2009; Asselin-Labat and Filby 2012; Hynes and Kelly 2012). The quantitative lineage-tracing strategies that have proven successful in resolving cell fates in normal epithelial tissues either using tissue-specific or stem-cell-specific transgenes (Barker et al. 2007; Clayton et al. 2007; Doupe et al. 2010; Lopez-Garcia et al. 2010; Snippert et al. 2010; de Visser et al. 2012; Mascre et al. 2012) or retroviral transduction (Mackenzie 1997; Ghazizadeh and Taichman 2001) are only starting to be used to follow primary tumor cells (reviewed in Alcolea and Jones 2013). Although marking tumor cells in their native environment offers certain advantages over tumor cell tracing in transplantation assays, the propensity of recombination-based approaches to activate double-strand break repair checkpoints (Zhu et al. 2012, 2013) may complicate the interpretation of data from cancer cells that have dysregulated these pathways.

The first cancer cell lineage-tracing reports focus on defining clonal architecture and clonal heterogeneity in two types of mouse tumors. To study clonal expansion in a colon adenoma model, Hans Clevers' group marked APC-deficient descendants of normal Lgr $5^{+}$colon stem cells (Barker et al. 2007) by means of retracing provided in a R26-confetti reporter line (Snippert et al. 2010). Under these conditions, single Lgr $5^{+}$adenoma cells appear to continuously contribute to adenoma growth at least up to $24 \mathrm{~d}$ after the concurrent activation of transformation and labeling and to give rise to multiple cell types in the adenoma (Schepers et al. 2012). If $\mathrm{Lgr5}^{+}$cells and their long-lived progeny are retained upon progression to colon carcinoma, then a similar marking strategy could be used to evaluate the contribution of individual clones to colon cancer metastasis. In skin papillomas, which were labeled at clonal density using conditional keratin 14-restricted Cre expression (Vasioukhin et al. 1999), Cedric Blanpain's group showed that cells at different stages of differentiation contribute to tumor formation, mature for only a few divisions and primitive for multiple cell divisions, resulting in a large number of uniformly small clones at early time point, day 9 postlabeling. Interestingly, these small size clones were virtually absent in squamous cell carcinomas of the skin (SCC) $9 \mathrm{~d}$ after a similar labeling protocol, where instead heterogeneity in clone size was observed (Driessens et al. 2012). Whether the clone size heterogeneity reflects a range of tumor-propagating abilities in individual cells dividing at the same rate or, conversely, a range of cell-cycle times in cells with similar tumor-propagating activity remains to be determined. In either case, once traced tumor cells can be followed for longer time periods, it may become possible to determine the timing and the frequency with which the marked cells can give rise to metastatic SCC. There is also an emergent strategy aimed at combining cell-separation approaches with lentiviral tracing of individual tumorcell subsets. Early evidence from Jeff Rosen's group suggests that it may be possible to study both 
clonality and propagation kinetics of barcodes in the tumor outgrowth by combining antibody-based flow sort analysis with lentiviral-borne 60mer genetic barcodes (Chang and Rosen 2012).

\section{Circulating Tumor Cells in Genetically Modified Models of Metastasis}

An early tumor graft study in mice showed that circulating tumor cells (CTCs) can spread from solid tumors (Liotta et al. 1974). However, isolation of CTCs from mouse blood remains a challenge, perhaps because of an extremely low number of tumor cells in the circulation, or perhaps because of lack of sufficiently sensitive detection methods. Clinically approved CTC platforms developed for the concentration of rare tumor cells from human blood rely on human-specific antigen expression (Kling 2012). Many experimental platforms are also antigen-dependent (Shah et al. 2012; Yu et al. 2013). Although there are reports of isolation of mouse tumor cells by marker expression (e.g., antiEpCAM antibodies were used to isolate mouse breast 4T1 tumor cells spiked into plasma-depleted blood [Shi et al. 2013], and FVB C3(1)-SV40 T-antigen mammary tumor cells were captured using a microfluidic-micromagnetic cell separation device [Kang et al. 2012]), variations between human and mouse antigens may compromise the analysis of mouse circulating cells. A label-free ISET (Isolation by Size of Epithelial Tumor cells) CTC technology is well suited for working with mouse models, as it is compatible with processing small sample volumes, is not restricted by tumor cell of origin, and allows the filtering of fixed as well as live cells, which is an advantage for study of metastasis-related factors in CTCs (Paterlini-Brechot 2011; Yu et al. 2012). As a putative marker of stem-cell capacity, at least in the mouse breast (Machado et al. 2013), cell size itself may be a promising parameter for the detection of the clinically relevant metastasis-initiating cells. The difference in size among tumor cells is sometimes a concern for this technology (Maheswaran and Haber 2010), but tumor cells in genetically modified models are perhaps best suited for size-based isolation, because their size is often uniform as a result of activation of an identical transformation program.

In the absence of effective methods of CTC isolation from live animals, earlier reports focused on quantification of disseminated tumor cells isolated after cardiac puncture or digestion of peripheral organs. For example, Carlos Arteaga's group cultivated disseminated cells from MMTV-PyMT transgenic mice (Muraoka et al. 2003; Biswas et al. 2007) using established protocols (Wyckoff et al. 2000). Another group reported using lungs from mice with PyMT-induced mammary tumors for harvest and RNA profiling of disseminated tumor cells (Franci et al. 2013). In the TRAMP metastatic prostate cancer model, cells isolated from blood after cardiac puncture were used to produce experimental metastases in immunodeficient recipients (Carvalho et al. 2013). Isolation of circulating cells from the blood or peripheral tissues may also be used to study the early spread of metastasis-initiating cells in genetically modified models. To date, several examples document the early spread of cancer in transgenic mice. For example, Christoph Klein's group detected cytokeratin-positive cells in the bone marrow of young MMTV-PyMT and MMTV-Neu transgenic mice, but not in the wild-type controls (Husemann et al. 2008). Another group used dissociated lung preparations to show the presence of colony-forming mammary cells in the lungs of very young (26-d-old) MMTV-PyMT transgenic mice (Weng et al. 2012). Finally, a YFP reporter was used to detect circulating pancreatic cells in the blood of tumor-free mice, in which pancreas-specific expression of Cre was used to delete Trp53, activate expression of mutant Kras, and induce a fluorescent reporter (Rhim et al. 2012). Tumor-specific fluorescent reporters will facilitate the development of continuous monitoring strategies for CTC levels in transgenic mice required to investigate early or late tumor-cell dissemination.

In summary, the current strategies that allow the sampling of genetic events that may be required for metastatic properties include both forward and reverse genetic approaches. The former are aimed at molecular characterization of the putative somatic alterations acquired with progression to metastasis, for example, by identifying the genotype or the transcriptional profile of tumor cells isolated from colonized organs or from the systemic circulation (reviewed in Paterlini-Brechot and Benali 2007; Yu et al. 2011). The latter are aimed at evaluation of a putative metastatic role of candidate molecules or signaling programs in genetically defined models-for example, using crossbreeding with animals that carry candidate alterations or using lentiviral delivery of candidate cDNAs 
F. Kabeer et al.

or shRNAs to tumor cells, often concomitant with permanent marking of the transduced cells (reviewed in Nguyen et al. 2009; Bos et al. 2010).

\section{Doxycycline-Regulated Oncogenes for Metastasis Studies}

The main advantage afforded by regulated expression of potent oncogenes is the ability to control the timing of tumor development, and thus to allow better kinetic control of tumor dissemination and/or colonization. For an in depth description of the tetracycline-inducible model, see Introduction: Tetracycline-Regulated Mouse Models of Cancer (Yeh et al. 2014). Our laboratory uses the reverse tetracycline transactivator (rtTA) configuration for temporal control of oncogene expression during different steps of the metastatic cascade (Podsypanina et al. 2008a,b). To do so, we first dissociate the solid tissue (normal or a primary tumor) into a single-cell suspension; see Protocol: Tissue Dissociation for Metastasis Studies (Kabeer and Podsypanina 2014).

We also use the inducible system to study oncogene cooperation in metastatic progression. Specifically, we use bicistronic retroviruses expressing the tetracycline transactivator (tTA) and the candidate gene (MIT-gene) or the tTA alone (MIT-Rx) (Beverly and Capobianco 2003) to infect primary mammary cells prepared from mice harboring doxycycline-inducible transgene(s). This system allows for constitutive expression of the candidate gene from the provirus and tTA-dependent expression of the inducible transgenic oncogene(s). Following infection of primary mammary cells ex vivo (see Protocol: Murine Stem Cell-Based Retrovirus Production for Marking Primary Mouse Mammary Cells for Metastasis Studies [Beverly and Podsypanina 2014]), cells are injected into the tail vein of syngeneic or immunodeficient recipients, and metastatic colonization is measured 3-6 wk after cell transfer. Cell marking with lentiviral vectors can be enhanced by lineage restriction using flow cytometry-based sorting of specific cell subsets in hierarchically organized tissues, as we and others (Chang and Rosen 2012) do in the mammary gland (see Protocol: Enrichment of Mammary Basal and Luminal Cells for Cell-of-Origin Metastasis Studies [Kabeer et al. 2014]). Such lineage restriction is helpful in addressing the cell-of-origin debate in metastasis research.

To measure the efficiency of metastatic colonization in the lung, we use intravital bioluminescence imaging, whole-organ bioluminescence imaging, and standard histopathological techniques, such as hematoxylin/eosin or immunohistochemical staining. A more recent approach is to enumerate tumor cells circulating in the blood of tumor- or metastasis-bearing animals. In the absence of specific markers for mammary cells, models with genetic marking of tumor cells give the best experimental advantage, but the low volume of peripheral blood that can be obtained from live animals limits the application of this technique to postmortem studies. We are looking forward to developing techniques that will allow us to monitor the kinetics of tumor burden in mouse models during anticancer treatments, as is being done for human patients (Maheswaran et al. 2008; Pachmann et al. 2008; Stott et al. 2010; Dawson et al. 2013; Hofman et al. 2013). Meanwhile, isolation of tumor cells from a colonizing tissue (e.g., the lung or bone [Husemann et al. 2008; Weng et al. 2012] [see Protocol: Tissue Dissociation for Metastasis Studies (Kabeer and Podsypanina 2016)]) can be an acceptable surrogate for measurement of colonization efficiency as well as for subsequent functional analysis of tumor cells.

In principle, the accompanying protocols cover the entire methodological approach to modeling metastasis in mice, whether one aims to begin with benign, transformed, or already metastatic cells (Fig. 1). Although we use these procedures to study metastatic colonization (i.e., using experimental metastasis-based approaches), these procedures are universal and can be applied to studies of spontaneous metastasis and invasion. In contrast, the extent of metastatic burden, although being the end result of each study, is often measured by methods unique to the study system (i.e., bioluminescence imaging, small-animal magnetic resonance imaging, fluorescence imaging, and histopathological or molecular analysis) and must be selected based on individual applications. In addition to the associated protocols that describe techniques to study metastasis in breast cancer models (see Protocol: Tissue Dissociation for Metastasis Studies [Kabeer and Podsypanina 2014], Protocol: Murine Stem Cell-Based Retrovirus Production for Marking Primary Mouse Mammary Cells for Metastasis 


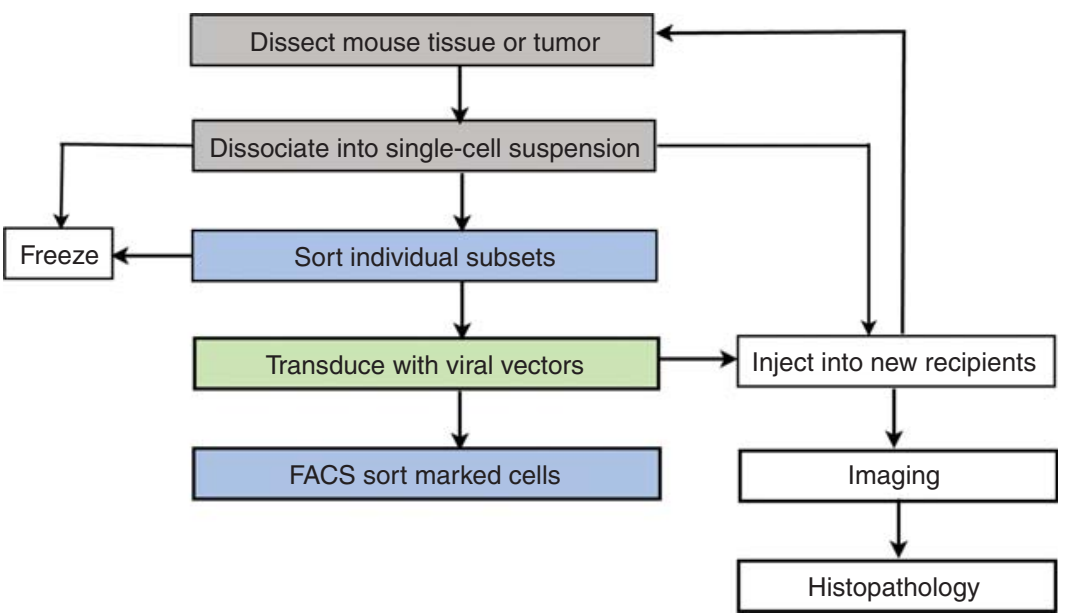

FIGURE 1. A schematic overview of the major steps in modeling metastasis. Steps shaded in gray are described in Protocol: Tissue Dissociation for Metastasis Studies (Kabeer and Podsypanina 2014), the step shaded in green is described in Protocol: Murine Stem Cell-Based Retrovirus Production for Marking Primary Mouse Mammary Cells for Metastasis Studies (Beverly and Podsypanina 2014), and steps shaded in blue are described in Protocol: Enrichment of Mammary Basal and Luminal Cells for Cell-of-Origin Metastasis Studies (Kabeer et al. 2014)

Studies [Beverly and Podsypanina 2014], and Protocol: Enrichment of Mammary Basal and Luminal Cells for Cell-of-Origin Metastasis Studies [Kabeer et al. 2014]), two additional protocols, Protocol: Isolating Epithelial and Epithelial-to-Mesenchymal Populations from Primary Tumors by Fluorescence-Activated Cell Sorting (Aiello et al. 2014a) and Protocol: Orthotopic Injection of Pancreatic Cancer Cells (Aiello et al. 2014b), highlight procedures to study cell lineages in pancreatic cancer models and to orthotopically inject tumor cells directly into the pancreas.

\section{ACKNOWLEDGMENTS}

I am grateful to members of my laboratory and to my coauthors who have optimized and streamlined the current protocols, to Katie Politi for the invitation to write this article, and to the Institut de Recherches Cliniques de Montréal for financing our effort to apply these protocols for a better understanding of cancer.

\section{REFERENCES}

Acuff HB, Carter KJ, Fingleton B, Gorden DL, Matrisian LM. 2006. Matrix metalloproteinase-9 from bone marrow-derived cells contributes to survival but not growth of tumor cells in the lung microenvironment. Cancer Res 66: 259-266.

Aiello NM, Rhim AD, Stanger BZ. 2014a. Isolating epithelial and epithelial-tomesenchymal populations from primary tumors by fluorescence-activated cell sorting. Cold Spring Harb Protoc doi: 10.1101/pdb.prot078352.

Aiello NM, Rhim AD, Stanger BZ. 2014b. Orthotopic injection of pancreatic cancer cells. Cold Spring Harb Protoc doi: 10.1101/pdb. prot078360.

Alcolea MP, Jones PH. 2013. Tracking cells in their native habitat: Lineage tracing in epithelial neoplasia. Nat Rev Cancer 13: 161-171.

Almholt K, Lund LR, Rygaard J, Nielsen BS, Dano K, Romer J, Johnsen M. 2005. Reduced metastasis of transgenic mammary cancer in urokinasedeficient mice. Int J Cancer 113: 525-532.

Antico Arciuch VG, Russo MA, Dima M, Kang KS, Dasrath F, Liao XH, Refetoff S, Montagna C, Di Cristofano A. 2011. Thyrocyte-specific inactivation of p53 and Pten results in anaplastic thyroid carcinomas faithfully recapitulating human tumors. Oncotarget 2: 1109-1126.

Asselin-Labat ML, Filby CE. 2012. Adult lung stem cells and their contribution to lung tumourigenesis. Open Biol 2: 120094.
Bardeesy N, Aguirre AJ, Chu GC, Cheng KH, Lopez LV, Hezel AF, Feng B, Brennan C, Weissleder R, Mahmood U, et al. 2006. Both p16 ${ }^{\text {Ink4a }}$ and the p19 $9^{\text {Arf }}$-p53 pathway constrain progression of pancreatic adenocarcinoma in the mouse. Proc Natl Acad Sci 103: 5947-5952.

Barker N, van Es JH, Kuipers J, Kujala P, van den Born M, Cozijnsen M, Haegebarth A, Korving J, Begthel H, Peters PJ, et al. 2007. Identification of stem cells in small intestine and colon by marker gene Lgr5. Nature 449: 1003-1007.

Beckerman R, Prives C. 2010. Transcriptional regulation by p53. Cold Spring Harb Perspect Biol 2: a000935.

Berger T, Ueda T, Arpaia E, Chio II, Shirdel EA, Jurisica I, Hamada K, YouTen A, Haight J, Wakeham A, et al. 2012. Flotillin-2 deficiency leads to reduced lung metastases in a mouse breast cancer model. Oncogene doi: 10.1038/onc.2012.499.

Berman SD, Calo E, Landman AS, Danielian PS, Miller ES, West JC, Fonhoue BD, Caron A, Bronson R, Bouxsein ML, et al. 2008. Metastatic osteosarcoma induced by inactivation of $\mathrm{Rb}$ and $\mathrm{p} 53$ in the osteoblast lineage. Proc Natl Acad Sci 105: 11851-11856.

Beverly LJ, Podsypanina K. 2014. Murine stem cell-based retrovirus production for marking primary mouse mammary cells for metastasis studies. Cold Spring Harb Protoc doi: 10.1101/pdb.prot078337. 


\section{F. Kabeer et al.}

Beverly LJ, Capobianco AJ. 2003. Perturbation of Ikaros isoform selection by MLV integration is a cooperative event in Notch(IC)-induced T cell leukemogenesis. Cancer Cell 3: 551-564.

Bierie B, Moses HL. 2009. Gain or loss of TGF $\beta$ signaling in mammary carcinoma cells can promote metastasis. Cell Cycle 8: 3319-3327.

Bierie B, Stover DG, Abel TW, Chytil A, Gorska AE, Aakre M, Forrester E, Yang L, Wagner KU, Moses HL. 2008. Transforming growth factor- $\beta$ regulates mammary carcinoma cell survival and interaction with the adjacent microenvironment. Cancer Res 68: 1809-1819.

Biswas S, Guix M, Rinehart C, Dugger TC, Chytil A, Moses HL, Freeman ML, Arteaga CL. 2007. Inhibition of TGF-beta with neutralizing antibodies prevents radiation-induced acceleration of metastatic cancer progression. J Clin Invest 117: 1305-1313.

Borczuk AC, Sole M, Lu P, Chen J, Wilgus ML, Friedman RA, Albelda SM, Powell CA. 2011. Progression of human bronchioloalveolar carcinoma to invasive adenocarcinoma is modeled in a transgenic mouse model of $\mathrm{K}$-ras-induced lung cancer by loss of the TGF- $\beta$ type II receptor. Cancer Res 71: 6665-6675.

Bos PD, Nguyen DX, Massague J. 2010. Modeling metastasis in the mouse. Curr Opin Pharmacol 10: 571-577.

Calbo J, Meuwissen R, van Montfort E, van Tellingen O, Berns A. 2005. Genotype-phenotype relationships in a mouse model for human smallcell lung cancer. Cold Spring Harb Symp Quant Biol 70: 225-232.

Carvalho FL, Simons BW, Antonarakis ES, Rasheed Z, Douglas N, Villegas D, Matsui W, Berman DM. 2013. Tumorigenic potential of circulating prostate tumor cells. Oncotarget 4: 413-421.

Chakrabarti R, Hwang J, Andres Blanco M, Wei Y, Lukacisin M, Romano RA, Smalley K, Liu S, Yang Q, Ibrahim T, et al. 2012. Elf5 inhibits the epithelial-mesenchymal transition in mammary gland development and breast cancer metastasis by transcriptionally repressing Snail2. Nat Cell Biol 14: 1212-1222.

on Chambers AF, MacDonald IC, Schmidt EE, Morris VL, Groom AC. 2000. Clinical targets for anti-metastasis therapy. Adv Cancer Res 79: 91-121.

(s) Chang EC, Rosen JM. 2012. Novel lentiviral barcoding strategy for lineage tracing of cancer stem cells. In AACR 103rd Annual Meeting. American Association for Cancer Research, Chicago, IL.

Charafe-Jauffret E, Ginestier C, Birnbaum D. 2009. Breast cancer stem cells: Tools and models to rely on. BMC Cancer 9: 202.

Chen YW, Klimstra DS, Mongeau ME, Tatem JL, Boyartchuk V, Lewis BC. 2007. Loss of $\mathrm{p} 53$ and Ink4a/Arf cooperate in a cell autonomous fashion to induce metastasis of hepatocellular carcinoma cells. Cancer Res 67: 7589-7596.

Cho SG, Li D, Tan K, Siwko SK, Liu M. 2012. KiSS1 and its G-proteincoupled receptor GPR54 in cancer development and metastasis. Cancer Metastasis Rev 31: 585-591.

Clayton E, Doupe DP, Klein AM, Winton DJ, Simons BD, Jones PH. 2007. A single type of progenitor cell maintains normal epidermis. Nature 446: $185-189$.

Cook LM, Cao X, Dowell AE, Debies MT, Edmonds MD, Beck BH, Kesterson RA, Desmond RA, Frost AR, Hurst DR, et al. 2012. Ubiquitous Brms1 expression is critical for mammary carcinoma metastasis suppression via promotion of apoptosis. Clin Exp Metastasis 29: 315-325.

Copeland BT, Bowman MJ, Ashman LK. 2012. Genetic ablation of the tetraspanin Cd151 reduces spontaneous metastatic spread of prostate cancer in the TRAMP model. Mol Cancer Res 11: 95-105.

Coschi CH, Martens AL, Ritchie K, Francis SM, Chakrabarti S, Berube NG, Dick FA. 2010. Mitotic chromosome condensation mediated by the retinoblastoma protein is tumor-suppressive. Genes Dev 24: 1351-1363.

Crnic I, Strittmatter K, Cavallaro U, Kopfstein L, Jussila L, Alitalo K, Christofori G. 2004. Loss of neural cell adhesion molecule induces tumor metastasis by up-regulating lymphangiogenesis. Cancer Res 64: 86308638.

Damsky WE, Curley DP, Santhanakrishnan M, Rosenbaum LE, Platt JT, Gould Rothberg BE, Taketo MM, Dankort D, Rimm DL, McMahon $\mathrm{M}$, et al. 2011. $\beta$-Catenin signaling controls metastasis in Braf-activated Pten-deficient melanomas. Cancer Cell 20: 741-754.

Dankort D, Curley DP, Cartlidge RA, Nelson B, Karnezis AN, Damsky WE Jr, You MJ, DePinho RA, McMahon M, Bosenberg M. 2009. $\mathrm{Braf}^{\mathrm{V} 600 \mathrm{E}}$ cooperates with Pten loss to induce metastatic melanoma. Nat Genet 41: 544-552.

Dawson SJ, Tsui DW, Murtaza M, Biggs H, Rueda OM, Chin SF, Dunning MJ, Gale D, Forshew T, Mahler-Araujo B, et al. 2013. Analysis of cir- culating tumor DNA to monitor metastatic breast cancer. N Engl J Med 368: 1199-1209.

de Visser KE, Ciampricotti M, Michalak EM, Tan DW, Speksnijder EN, Hau CS, Clevers H, Barker N, Jonkers J. 2012. Developmental stage-specific contribution of LGR5 ${ }^{+}$cells to basal and luminal epithelial lineages in the postnatal mammary gland. J Pathol 228: 300-309.

Deroose CM, De A, Loening AM, Chow PL, Ray P, Chatziioannou AF, Gambhir SS. 2007. Multimodality imaging of tumor xenografts and metastases in mice with combined small-animal PET, small-animal CT, and bioluminescence imaging. J Nucl Med 48: 295-303.

Doupe DP, Klein AM, Simons BD, Jones PH. 2010. The ordered architecture of murine ear epidermis is maintained by progenitor cells with random fate. Dev Cell 18: 317-323.

Driessens G, Beck B, Caauwe A, Simons BD, Blanpain C. 2012. Defining the mode of tumour growth by clonal analysis. Nature 488: 527-530.

Du YC, Lewis BC, Hanahan D, Varmus H. 2007. Assessing tumor progression factors by somatic gene transfer into a mouse model: Bcl-xL promotes islet tumor cell invasion. PLoS Biol 5: e276.

Du YC, Chou CK, Klimstra DS, Varmus H. 2011. Receptor for hyaluronanmediated motility isoform B promotes liver metastasis in a mouse model of multistep tumorigenesis and a tail vein assay for metastasis. Proc Natl Acad Sci 108: 16753-16758.

Faltas B. 2012. Cornering metastases: Therapeutic targeting of circulating tumor cells and stem cells. Front Oncol 2: 68.

Fang WB, Jokar I, Chytil A, Moses HL, Abel T, Cheng N. 2011. Loss of one Tgfbr2 allele in fibroblasts promotes metastasis in MMTV: Polyoma middle $\mathrm{T}$ transgenic and transplant mouse models of mammary tumor progression. Clin Exp Metastasis 28: 351-366.

Fantozzi A, Christofori G. 2006. Mouse models of breast cancer metastasis. Breast Cancer Res 8: 212.

Fedorov LM, Papadopoulos T, Tyrsin OY, Twardzik T, Gotz R, Rapp UR. 2003. Loss of p53 in craf-induced transgenic lung adenoma leads to tumor acceleration and phenotypic switch. Cancer Res 63: 22682277.

Fidler IJ. 1973. Selection of successive tumour lines for metastasis. Nature 242: 148-149.

Fiorentino FP, Marchesi I, Giordano A. 2013. On the role of retinoblastoma family proteins in the establishment and maintenance of the epigenetic landscape. J Cell Physiol 228: 276-284.

Flaherty KT, Puzanov I, Kim KB, Ribas A, McArthur GA, Sosman JA, O’Dwyer PJ, Lee RJ, Grippo JF, Nolop K, et al. 2010. Inhibition of mutated, activated BRAF in metastatic melanoma. $N$ Engl J Med 363: 809-819.

Forrester E, Chytil A, Bierie B, Aakre M, Gorska AE, Sharif-Afshar AR, Muller WJ, Moses HL. 2005. Effect of conditional knockout of the type II TGF- $\beta$ receptor gene in mammary epithelia on mammary gland development and polyomavirus middle $\mathrm{T}$ antigen induced tumor formation and metastasis. Cancer Res 65: 2296-2302.

Franci C, Zhou J, Jiang Z, Modrusan Z, Good Z, Jackson E, Kouros-Mehr H. 2013. Biomarkers of residual disease, disseminated tumor cells, and metastases in the MMTV-PyMT breast cancer model. PLoS ONE 8: e58183.

Fukasawa K, Choi T, Kuriyama R, Rulong S, Vande Woude GF. 1996. Abnormal centrosome amplification in the absence of p53. Science 271: 1744-1747.

Fushiki H, Kanoh-Azuma T, Katoh M, Kawabata K, Jiang J, Tsuchiya N, Satow A, Tamai Y, Hayakawa Y. 2009. Quantification of mouse pulmonary cancer models by microcomputed tomography imaging. Cancer Sci 100: 1544-1549.

Ghazizadeh S, Taichman LB. 2001. Multiple classes of stem cells in cutaneous epithelium: A lineage analysis of adult mouse skin. Embo J 20: 12151222.

Gingrich JR, Barrios RJ, Morton RA, Boyce BF, DeMayo FJ, Finegold MJ, Angelopoulou R, Rosen JM, Greenberg NM. 1996. Metastatic prostate cancer in a transgenic mouse. Cancer Res 56: 4096-4102.

Guigon CJ, Zhao L, Willingham MC, Cheng SY. 2009. PTEN deficiency accelerates tumour progression in a mouse model of thyroid cancer. Oncogene 28: 509-517.

Gunther EJ, Moody SE, Belka GK, Hahn KT, Innocent N, Dugan KD, Cardiff RD, Chodosh LA. 2003. Impact of p53 loss on reversal and recurrence of conditional Wnt-induced tumorigenesis. Genes Dev 17: $488-501$. 
Guy CT, Cardiff RD, Muller WJ. 1992. Induction of mammary tumors by expression of polyomavirus middle $\mathrm{T}$ oncogene: A transgenic mouse model for metastatic disease. Mol Cell Biol 12: 954-961.

Han G, Buchanan G, Ittmann M, Harris JM, Yu X, Demayo FJ, Tilley W, Greenberg NM. 2005. Mutation of the androgen receptor causes oncogenic transformation of the prostate. Proc Natl Acad Sci 102: 1151-1156.

Hanahan D. 1985. Heritable formation of pancreatic beta-cell tumours in transgenic mice expressing recombinant insulin/simian virus 40 oncogenes. Nature 315: 115-122.

Heijstek MW, Kranenburg O, Borel Rinkes IH. 2005. Mouse models of colorectal cancer and liver metastases. Dig Surg 22: 16-25.

Heldin CH, Miyazono K, ten Dijke P. 1997. TGF-beta signalling from cell membrane to nucleus through SMAD proteins. Nature 390: 465471.

Hingorani SR, Wang L, Multani AS, Combs C, Deramaudt TB, Hruban RH, Rustgi AK, Chang S, Tuveson DA. 2005. Trp53R172H and KrasG12D cooperate to promote chromosomal instability and widely metastatic pancreatic ductal adenocarcinoma in mice. Cancer Cell 7: 469-483.

Hofman V, Ilie M, Long-Mira E, Giacchero D, Butori C, Dadone B, Selva E, Tanga V, Passeron T, Poissonnet G, et al. 2013. Usefulness of immunocytochemistry for the detection of the $\mathrm{BRAF}^{\mathrm{V} 600 \mathrm{E}}$ mutation in circulating tumor cells from metastatic melanoma patients. J Invest Dermatol 133: 1378-1381.

Hotta K, Kiura K, Ueoka H, Tabata M, Fujiwara K, Kozuki T, Okada T, Hisamoto A, Tanimoto M. 2004. Effect of gefitinib ('Iressa', ZD1839) on brain metastases in patients with advanced non-small-cell lung cancer. Lung Cancer 46: 255-261.

Husaini Y, Qiu MR, Lockwood GP, Luo XW, Shang P, Kuffner T, Tsai VW, Jiang L, Russell PJ, Brown DA, et al. 2012. Macrophage inhibitory cytokine-1 (MIC-1/GDF15) slows cancer development but increases metastases in TRAMP prostate cancer prone mice. PLoS ONE 7: e43833.

Husemann Y, Klein CA. 2009. The analysis of metastasis in transgenic mouse models. Transgenic Res 18: 1-5.

Husemann Y, Geigl JB, Schubert F, Musiani P, Meyer M, Burghart E, Forn G, Eils R, Fehm T, Riethmuller G, et al. 2008. Systemic spread is an early step in breast cancer. Cancer Cell 13: 58-68.

Hynes PG, Kelly K. 2012. Prostate cancer stem cells: The case for model systems. J Carcinog 11: 6.

Kabeer F, Podsypanina K. 2014. Tissue dissociation for metastasis studies. Cold Spring Harb Protoc doi: 10.1101/pdb.prot078329.

Kabeer F, Podsypanina K, Darrasse-Jèze G. 2014. Enrichment of mammary basal and luminal cells for cell-of-origin metastasis studies. Cold Spring Harb Protoc doi: 10.1101/pdb.prot078345.

Kang Y, Siegel PM, Shu W, Drobnjak M, Kakonen SM, Cordon-Cardo C, Guise TA, Massague J. 2003. A multigenic program mediating breast cancer metastasis to bone. Cancer Cell 3: 537-549.

Kang JH, Krause S, Tobin H, Mammoto A, Kanapathipillai M, Ingber DE. 2012. A combined micromagnetic-microfluidic device for rapid capture and culture of rare circulating tumor cells. Lab Chip 12: 2175-2181.

Kirsch DG, Grimm J, Guimaraes AR, Wojtkiewicz GR, Perez BA, Santiago PM, Anthony NK, Forbes T, Doppke K, Weissleder R, et al. 2010 Imaging primary lung cancers in mice to study radiation biology. Int J Radiat Oncol Biol Phys 76: 973-977.

Klein CA. 2009. Parallel progression of primary tumours and metastases. Nat Rev Cancer 9: 302-312.

Kling J. 2012. Beyond counting tumor cells. Nat Biotechnol 30: 578-580.

Kren A, Baeriswyl V, Lehembre F, Wunderlin C, Strittmatter K, Antoniadis H, Fassler R, Cavallaro U, Christofori G. 2007. Increased tumor cell dissemination and cellular senescence in the absence of $\beta 1$-integrin function. EMBO J 26: 2832-2842.

Krupnick AS, Tidwell VK, Engelbach JA, Alli VV, Nehorai A, You M, Vikis HG, Gelman AE, Kreisel D, Garbow JR. 2012. Quantitative monitoring of mouse lung tumors by magnetic resonance imaging. Nat Protoc 7 $128-142$.

Lahlou H, Muller WJ. 2011. $\beta 1$-integrins signaling and mammary tumor progression in transgenic mouse models: Implications for human breast cancer. Breast Cancer Res 13: 229.

Landsberg J, Gaffal E, Cron M, Kohlmeyer J, Renn M, Tuting T. 2010. Autochthonous primary and metastatic melanomas in Hgf-Cdk4 R24C mice evade T-cell-mediated immune surveillance. Pigment Cell Melanoma Res 23: 649-660.
Lewis BC, Klimstra DS, Socci ND, Xu S, Koutcher JA, Varmus HE. 2005. The absence of p53 promotes metastasis in a novel somatic mouse model for hepatocellular carcinoma. Mol Cell Biol 25: 1228-1237.

Lin SC, Lee KF, Nikitin AY, Hilsenbeck SG, Cardiff RD, Li A, Kang KW, Frank SA, Lee WH, Lee EY. 2004. Somatic mutation of p53 leads to estrogen receptor $\alpha$-positive and -negative mouse mammary tumors with high frequency of metastasis. Cancer Res 64: 3525-3532.

Liotta LA, Kleinerman J, Saidel GM. 1974. Quantitative relationships of intravascular tumor cells, tumor vessels, and pulmonary metastases following tumor implantation. Cancer Res 34: 997-1004.

Lopez T, Hanahan D. 2002. Elevated levels of IGF-1 receptor convey invasive and metastatic capability in a mouse model of pancreatic islet tumorigenesis. Cancer Cell 1: 339-353.

Lopez-Garcia C, Klein AM, Simons BD, Winton DJ. 2010. Intestinal stem cell replacement follows a pattern of neutral drift. Science 330: 822-825.

Machado HL, Kittrell FS, Edwards D, White AN, Atkinson RL, Rosen JM, Medina D, Lewis MT. 2013. Separation by cell size enriches for mammary stem cell repopulation activity. Stem Cells Transl Med 2: 199-203.

Mackenzie IC. 1997. Retroviral transduction of murine epidermal stem cells demonstrates clonal units of epidermal structure. J Invest Dermatol 109: 377-383.

Maheswaran S, Haber DA. 2010. Circulating tumor cells: A window into cancer biology and metastasis. Curr Opin Genet Dev 20: 96-99.

Maheswaran S, Sequist LV, Nagrath S, Ulkus L, Brannigan B, Collura CV, Inserra E, Diederichs S, Iafrate AJ, Bell DW, et al. 2008. Detection of mutations in EGFR in circulating lung-cancer cells. N Engl J Med 359: 366-377.

Mandriota SJ, Jussila L, Jeltsch M, Compagni A, Baetens D, Prevo R, Banerji S, Huarte J, Montesano R, Jackson DG, et al. 2001. Vascular endothelial growth factor-C-mediated lymphangiogenesis promotes tumour metastasis. Embo J 20: 672-682.

Manning AL, Longworth MS, Dyson NJ. 2010. Loss of pRB causes centromere dysfunction and chromosomal instability. Genes Dev 24: 1364-1376.

Marino N, Nakayama J, Collins JW, Steeg PS. 2012. Insights into the biology and prevention of tumor metastasis provided by the $\mathrm{Nm} 23$ metastasis suppressor gene. Cancer Metastasis Rev 31: 593-603.

Maroulakou IG, Shibata MA, Jorcyk CL, Chen XX, Green JE. 1997. Reduced $p 53$ dosage associated with mammary tumor metastases in $\mathrm{C} 3(1) / \mathrm{T}_{\mathrm{AG}}$ transgenic mice. Mol Carcinog 20: 168-174.

Mascre G, Dekoninck S, Drogat B, Youssef KK, Brohee S, Sotiropoulou PA, Simons BD, Blanpain C. 2012. Distinct contribution of stem and progenitor cells to epidermal maintenance. Nature 489: 257-262.

Massague J, Chen YG. 2000. Controlling TGF- $\beta$ signaling. Genes Dev 14: $627-644$.

Meuwissen R, Linn SC, Linnoila RI, Zevenhoven J, Mooi WJ, Berns A. 2003. Induction of small cell lung cancer by somatic inactivation of both Trp53 and Rb1 in a conditional mouse model. Cancer Cell 4: 181-189.

Minn AJ, Gupta GP, Siegel PM, Bos PD, Shu W, Giri DD, Viale A, Olshen AB, Gerald WL, Massague J. 2005. Genes that mediate breast cancer metastasis to lung. Nature 436: 518-524.

Moody SE, Sarkisian CJ, Hahn KT, Gunther EJ, Pickup S, Dugan KD, Innocent N, Cardiff RD, Schnall MD, Chodosh LA. 2002. Conditional activation of Neu in the mammary epithelium of transgenic mice results in reversible pulmonary metastasis. Cancer Cell 2: 451-461.

Moore ML, Teitell MA, Kim Y, Watabe T, Reiter RE, Witte ON, Dubey P. 2008. Deletion of PSCA increases metastasis of TRAMP-induced prostate tumors without altering primary tumor formation. Prostate 68: 139-151.

Morton JP, Klimstra DS, Mongeau ME, Lewis BC. 2008. Trp53 deletion stimulates the formation of metastatic pancreatic tumors. Am J Pathol 172: 1081-1087.

Muller WJ, Sinn E, Pattengale PK, Wallace R, Leder P. 1988. Single-step induction of mammary adenocarcinoma in transgenic mice bearing the activated c-neu oncogene. Cell 54: 105-115.

Muraoka RS, Koh Y, Roebuck LR, Sanders ME, Brantley-Sieders D, Gorska $\mathrm{AE}$, Moses HL, Arteaga CL. 2003. Increased malignancy of Neuinduced mammary tumors overexpressing active transforming growth factor beta1. Mol Cell Biol 23: 8691-8703.

Muraoka-Cook RS, Kurokawa H, Koh Y, Forbes JT, Roebuck LR, BarcellosHoff MH, Moody SE, Chodosh LA, Arteaga CL. 2004. Conditional 
overexpression of active transforming growth factor betal in vivo accelerates metastases of transgenic mammary tumors. Cancer Res 64: 9002-9011.

Nguyen DX, Bos PD, Massague J. 2009. Metastasis: From dissemination to organ-specific colonization. Nat Rev Cancer 9: 274-284.

Novitskiy SV, Pickup MW, Gorska AE, Owens P, Chytil A, Aakre M, Wu H, Shyr Y, Moses HL. 2011. TGF- $\beta$ receptor II loss promotes mammary carcinoma progression by Th17 dependent mechanisms. Cancer Discov 1: 430-441.

Pachmann K, Camara O, Kavallaris A, Krauspe S, Malarski N, Gajda M, Kroll T, Jorke C, Hammer U, Altendorf-Hofmann A, et al. 2008. Monitoring the response of circulating epithelial tumor cells to adjuvant chemotherapy in breast cancer allows detection of patients at risk of early relapse. J Clin Oncol 26: 1208-1215.

Paterlini-Brechot P. 2011. Organ-specific markers in circulating tumor cell screening: An early indicator of metastasis-capable malignancy. Future Oncol 7: 849-871.

Paterlini-Brechot P, Benali NL. 2007. Circulating tumor cells (CTC) detection: Clinical impact and future directions. Cancer Lett 253: 180-204.

Perl AK, Wilgenbus P, Dahl U, Semb H, Christofori G. 1998. A causal role for E-cadherin in the transition from adenoma to carcinoma. Nature 392: $190-193$.

Perl AK, Dahl U, Wilgenbus P, Cremer H, Semb H, Christofori G. 1999. Reduced expression of neural cell adhesion molecule induces metastatic dissemination of pancreatic $\beta$ tumor cells. Nat Med 5: 286-291.

Podsypanina K, Du YC, Jechlinger M, Beverly LJ, Hambardzumyan D, Varmus H. 2008a. Seeding and propagation of untransformed mouse mammary cells in the lung. Science 321: 1841-1844.

Podsypanina K, Politi K, Beverly LJ, Varmus HE. 2008b. Oncogene cooperation in tumor maintenance and tumor recurrence in mouse mammary tumors induced by Myc and mutant Kras. Proc Natl Acad Sci 105: 5242-5247.

¿ Puc J, Keniry M, Li HS, Pandita TK, Choudhury AD, Memeo L, Mansukhani M, Murty VV, Gaciong Z, Meek SE, et al. 2005. Lack of PTEN sequesters CHK1 and initiates genetic instability. Cancer Cell 7: 193-204.

Puzio-Kuter AM, Castillo-Martin M, Kinkade CW, Wang X, Shen TH, Matos T, Shen MM, Cordon-Cardo C, Abate-Shen C. 2009. Inactivation of p53 and Pten promotes invasive bladder cancer. Genes Dev 23: 675-680.

Qian F, Hanahan D, Weissman IL. 2001. L-selectin can facilitate metastasis to lymph nodes in a transgenic mouse model of carcinogenesis. Proc Natl Acad Sci 98: 3976-3981.

Ramaswamy S, Ross KN, Lander ES, Golub TR. 2003. A molecular signature of metastasis in primary solid tumors. Nat Genetics 33: 49-54.

Rapp UR, Korn C, Ceteci F, Karreman C, Luetkenhaus K, Serafin V, Zanucco E, Castro I, Potapenko T. 2009. MYC is a metastasis gene for non-small-cell lung cancer. PLoS ONE 4: e6029.

Rhim AD, Mirek ET, Aiello NM, Maitra A, Bailey JM, McAllister F, Reichert M, Beatty GL, Rustgi AK, Vonderheide RH, et al. 2012. EMT and dissemination precede pancreatic tumor formation. Cell 148: 349-361.

Ridgeway AG, McMenamin J, Leder P. 2006. P53 levels determine outcome during beta-catenin tumor initiation and metastasis in the mammary gland and male germ cells. Oncogene 25: 3518-3527.

Sale S, Orsulic S. 2006. Models of ovarian cancer metastasis: Murine models. Drug Discov Today 3: 149-154.

Schade B, Rao T, Dourdin N, Lesurf R, Hallett M, Cardiff RD, Muller WJ. 2009. PTEN deficiency in a luminal ErbB-2 mouse model results in dramatic acceleration of mammary tumorigenesis and metastasis. $J$ Biol Chem 284: 19018-19026.

Schepers AG, Snippert HJ, Stange DE, van den Born M, van Es JH, van de Wetering M, Clevers H. 2012. Lineage tracing reveals Lgr $5^{+}$stem cell activity in mouse intestinal adenomas. Science 337: 730-735.

Schiffner S, Chen S, Becker JC, Bosserhoff AK. 2012. Highly pigmented $\mathrm{Tg}^{\mathrm{Grm} 1}$ mouse melanoma develops non-pigmented melanoma cells in distant metastases. Exp Dermatol 21: 786-788.

Schmidt-Kittler O, Ragg T, Daskalakis A, Granzow M, Ahr A, Blankenstein TJ, Kaufmann M, Diebold J, Arnholdt H, Muller P, et al. 2003. From latent disseminated cells to overt metastasis: Genetic analysis of systemic breast cancer progression. Proc Natl Acad Sci 100: 7737-7742.

Schneeweiss A, Kolay S, Aulmann S, Von Minckwitz G, Torode J, Koehler M, Bastert G. 2004. Induction of remission in a patient with metastatic breast cancer refractory to trastuzumab and chemotherapy following treatment with gefitinib ('Iressa', ZD1839). Anticancer Drugs 15: 235238.

Shachaf CM, Kopelman AM, Arvanitis C, Karlsson A, Beer S, Mandl S, Bachmann MH, Borowsky AD, Ruebner B, Cardiff RD, et al. 2004 MYC inactivation uncovers pluripotent differentiation and tumour dormancy in hepatocellular cancer. Nature 431: 1112-1117.

Shah AM, Yu M, Nakamura Z, Ciciliano J, Ulman M, Kotz K, Stott SL, Maheswaran S, Haber DA, Toner M. 2012. Biopolymer system for cell recovery from microfluidic cell capture devices. Anal Chem 84: 3682-3688

Shi G, Cui W, Benchimol M, Liu YT, Mattrey RF, Mukthavaram R, Kesari S, Esener SC, Simberg D. 2013. Isolation of rare tumor cells from blood cells with buoyant immuno-microbubbles. PLoS ONE 8: e58017.

Siegel PM, Shu W, Cardiff RD, Muller WJ, Massague J. 2003. Transforming growth factor beta signaling impairs Neu-induced mammary tumorigenesis while promoting pulmonary metastasis. Proc Natl Acad Sci 100: 8430-8435.

Snippert HJ, van der Flier LG, Sato T, van Es JH, van den Born M, KroonVeenboer C, Barker N, Klein AM, van Rheenen J, Simons BD, et al. 2010. Intestinal crypt homeostasis results from neutral competition between symmetrically dividing Lgr5 stem cells. Cell 143: 134-144.

Stahel R, Rossi A, Petruzelka L, Kosimidis P, de Braud F, Bernardo MM, Souquet PJ, Parra HS, Gridelli C. 2003. Lessons from the 'Iressa' Expanded Access Programme: Gefitinib in special non-small-cell lung cancer patient populations. Br J Cancer 89: 19-23.

Stoecklein NH, Klein CA. 2010. Genetic disparity between primary tumours, disseminated tumour cells, and manifest metastasis. Int J Cancer 126: 589-598.

Stott SL, Hsu CH, Tsukrov DI, Yu M, Miyamoto DT, Waltman BA, Rothenberg SM, Shah AM, Smas ME, Korir GK, et al. 2010. Isolation of circulating tumor cells using a microvortex-generating herringbonechip. Proc Natl Acad Sci 107: 18392-18397.

Tevethia MJ, Bonneau RH, Griffith JW, Mylin L. 1997. A simian virus 40 large T-antigen segment containing amino acids 1 to 127 and expressed under the control of the rat elastase- 1 promoter produces pancreatic acinar carcinomas in transgenic mice. J Virol 71: 8157-8166.

Tu WH, Thomas TZ, Masumori N, Bhowmick NA, Gorska AE, Shyr Y, Kasper S, Case T, Roberts RL, Shappell SB, et al. 2003. The loss of TGF-beta signaling promotes prostate cancer metastasis. Neoplasia 5: 267-277.

van 't Veer LJ, Dai H, van de Vijver MJ, He YD, Hart AA, Mao M, Peterse HL, van der Kooy K, Marton MJ, Witteveen AT, et al. 2002. Gene expression profiling predicts clinical outcome of breast cancer. Nature 415: 530-536.

van Harn T, Foijer F, van Vugt M, Banerjee R, Yang F, Oostra A, Joenje H, te Riele H. 2010. Loss of $\mathrm{Rb}$ proteins causes genomic instability in the absence of mitogenic signaling. Genes Dev 24: 1377-1388.

Vasioukhin V, Degenstein L, Wise B, Fuchs E. 1999. The magical touch: Genome targeting in epidermal stem cells induced by tamoxifen application to mouse skin. Proc Natl Acad Sci 96: 8551-8556.

Vernon AE, Bakewell SJ, Chodosh LA. 2007. Deciphering the molecular basis of breast cancer metastasis with mouse models. Rev Endocr Metab Disord 8: 199-213.

Wang Y, Klijn JG, Zhang Y, Sieuwerts AM, Look MP, Yang F, Talantov D, Timmermans M, Meijer-van Gelder ME, Yu J, et al. 2005. Gene-expression profiles to predict distant metastasis of lymph-node-negative primary breast cancer. Lancet 365: 671-679.

Wang Y, Tseng J-C, Sun Y, Beck AH, Kung AL. 2014. Noninvasive imaging of tumor burden and molecular pathways in mouse models of cancer. Cold Spring Harb Protoc doi: 10.1101/pdb.top069930.

Weng D, Penzner JH, Song B, Koido S, Calderwood SK, Gong J. 2012. Metastasis is an early event in mouse mammary carcinomas and is associated with cells bearing stem cell markers. Breast Cancer Res 14: R18.

Williams TM, Medina F, Badano I, Hazan RB, Hutchinson J, Muller WJ, Chopra NG, Scherer PE, Pestell RG, Lisanti MP. 2004. Caveolin-1 gene disruption promotes mammary tumorigenesis and dramatically enhances lung metastasis in vivo. Role of Cav-1 in cell invasiveness and matrix metalloproteinase (MMP-2/9) secretion. J Biol Chem 279: $51630-51646$.

Williams TM, Hassan GS, Li J, Cohen AW, Medina F, Frank PG, Pestell RG, Di Vizio D, Loda M, Lisanti MP. 2005. Caveolin-1 promotes tumor progression in an autochthonous mouse model of prostate cancer: 
Genetic ablation of Cav-1 delays advanced prostate tumor development in tramp mice. J Biol Chem 280: 25134-25145.

Winslow MM, Dayton TL, Verhaak RG, Kim-Kiselak C, Snyder EL, Feldser DM, Hubbard DD, DuPage MJ, Whittaker CA, Hoersch S, et al. 2011. Suppression of lung adenocarcinoma progression by $\mathrm{Nkx2}-1$. Nature 473: 101-104.

Wyckoff JB, Jones JG, Condeelis JS, Segall JE. 2000. A critical step in metastasis: In vivo analysis of intravasation at the primary tumor. Cancer Res 60: 2504-2511.

Yang YA, Dukhanina O, Tang B, Mamura M, Letterio JJ, MacGregor J, Patel SC, Khozin S, Liu ZY, Green J, et al. 2002. Lifetime exposure to a soluble TGF- $\beta$ antagonist protects mice against metastasis without adverse side effects. J Clin Invest 109: 1607-1615.

Yang L, Huang J, Ren X, Gorska AE, Chytil A, Aakre M, Carbone DP, Matrisian LM, Richmond A, Lin PC, et al. 2008. Abrogation of TGF beta signaling in mammary carcinomas recruits Gr-1+CD11b+ myeloid cells that promote metastasis. Cancer Cell 13: 23-35.

Yeh ES, Vernon-Grey A, Martin H, Chodosh LA. 2014. Tetracycline-regulated mouse models of cancer. Cold Spring Harb Protoc doi: 10.1101/ pdb.top069823.
Yin Y, Tainsky MA, Bischoff FZ, Strong LC, Wahl GM. 1992. Wild-type p53 restores cell cycle control and inhibits gene amplification in cells with mutant p53 alleles. Cell 70: 937-948.

Yu M, Stott S, Toner M, Maheswaran S, Haber DA. 2011. Circulating tumor cells: Approaches to isolation and characterization. J Cell Biol 192: 373382.

Yu M, Ting DT, Stott SL, Wittner BS, Ozsolak F, Paul S, Ciciliano JC, Smas ME, Winokur D, Gilman AJ, et al. 2012. RNA sequencing of pancreatic circulating tumour cells implicates WNT signalling in metastasis. Nature 487: 510-513.

Yu M, Bardia A, Wittner BS, Stott SL, Smas ME, Ting DT, Isakoff SJ, Ciciliano JC, Wells MN, Shah AM, et al. 2013. Circulating breast tumor cells exhibit dynamic changes in epithelial and mesenchymal composition. Science 339: 580-584.

Zhu J, Nguyen MT, Nakamura E, Yang J, Mackem S. 2012. Cre-mediated recombination can induce apoptosis in vivo by activating the p53 DNA damage-induced pathway. Genesis 50: 102-111.

Zhu Y, Huang YF, Kek C, Bulavin DV. 2013. Apoptosis differently affects lineage tracing of Lgr5 and Bmil intestinal stem cell populations. Cell Stem Cell 12: 298-303. 


\section{Methods to Study Metastasis in Genetically Modified Mice}

Farhia Kabeer, Levi J. Beverly, Guillaume Darrasse-Jèze and Katrina Podsypanina

Cold Spring Harb Protoc; doi: 10.1101/pdb.top069948

\begin{tabular}{|c|c|}
\hline $\begin{array}{r}\text { Email Alerting } \\
\text { Service }\end{array}$ & Receive free email alerts when new articles cite this article - click here. \\
\hline $\begin{array}{l}\text { Subject } \\
\text { Categories }\end{array}$ & $\begin{array}{l}\text { Browse articles on similar topics from Cold Spring Harbor Protocols. } \\
\text { Cell Biology, general (1382 articles) } \\
\text { Mouse (437 articles) } \\
\text { Transgenic Mice (139 articles) }\end{array}$ \\
\hline
\end{tabular}

